\title{
The language functions of tipo in Argentine vernacular
}

\author{
Julieta Fernández \\ University of Arizona, Department of Spanish and Portuguese, Modern \\ Languages 545, 1423 E. University Blvd., Tucson, AZ 85721, United States
}

\begin{abstract}
This article provides a case study account of the language functions of tipo, which is a pragmatic feature of Argentine Spanish vernacular, as used by 10 young adult native speakers of the language (ages 18-25), in the context of oral face-to-face and synchronous technology-mediated written interactions with young adult Spanish L2 learners. An examination of naturally occurring and selfreported language awareness data suggests that tipo has acquired a wide array of pragmatic functions - it is a marker of hesitation, exemplification, reformulation, vagueness, and quoted speech. In its non-pragmatic marking uses, it can refer to an unspecified man, preface a hyponym, and be used to make a comparison. Participants' usage patterns, in conjunction with their understanding of sociopragmatic variability in the use of tipo, are discussed as a direction for research in colloquial features of youth vernacular.
\end{abstract}

Keywords:

Argentine Spanish; computer-mediated communication (CMC); pragmatic markers; youth vernacular 


\section{Introduction}

Interest in researching the characteristics of the language used by teenagers and young adults has increased in the last 20 years. However, there are still very few studies in this area, especially in regard to languages other than English (Stenström, Andersen, and Hasund, 2002) among which Spanish in particular has been neglected (Rodríguez, 2002). Zimmermann (1996) makes the case that youth vernacular does not receive much attention because the social group that uses this variety is considered marginal-young people are underage and economically dependent. Importantly, the characteristics of their speech are short-lived; new words are adopted and old ones acquire new meanings at a fast pace (Zimmermann, 1996). From a research perspective, the nearer we get to "the vernacular," teenage and young adult talk is "likely to play a part in language change and often works its way into 'standard' language" (Stenström et al., 2002: $x)$.

Prior applied linguistics research has revealed that one of the most distinctive characteristics of teenage and young adult language is its vocabulary; an example in English is the prevalence of like and go over say as quotative verbs (Stenström et al., 2002). Teenagers and young adults have also been found to imbue old words with new meanings. To be sure, the way these speakers talk draws criticism from parents and instructors alike, especially their 
"use of slang, vague and dirty words, often in combination with a lot of 'unnecessary' smallwords, especially like" (Stenström et al., 2002:63). However, a linguistic focus on these features is essential, as they are very frequent and thus constitute a defining characteristic of conversational grammar, "but are found much more frequently in adolescent conversation" (Stenström, 2012:2411). More importantly, they are often used as an expression of a shared experience (Rymes, 2011) or markers of peer-group membership (Tagliamonte, 2016). Despite being "referentially opaque," expressions such as tipo "indicate not that their speakers are vacuous but that these words encapsulate ambiguities too complex or localized to express explicitly" (Rymes, 2011:208).

The term 'youth vernacular' here refers to the language production of Argentine undergraduate students during the spring of 2012 when the data were collected. Tipo, a feature of youth vernacular, is frequently used in, and is thus a hallmark of unplanned spoken interactions among young speakers of Argentine Spanish. The aim of this study is two-fold: (1) to provide a case-study account of the uses of tipo (which roughly serves similar functions as type, guy, like and around in American English), a colloquial lexical feature characteristic of Argentine Spanish vernacular, as spoken by 10 young adult native speakers of the language (ages 18-25). These uses are in the context of oral face-to-face interactions and technology-mediated written interactions (i.e., text chat) with 
young adult Americans (ages 18-22) who were studying L2 Spanish in Argentina;

(2) to characterize its contexts of use, levels of formality, and any additional layers of meaning (e.g., stereotypes) based on the participants' responses to a language awareness test. Overall, this study blends a discourse analytic description of the linguistic patterns that emerged from the participants' documented language performance together with the analysis of participants' metapragmatic awareness of their social functions.

2. The use of tipo in Argentine Spanish

According to recent dictionaries of Argentine vernacular Spanish, tipo is most frequently used in colloquial Spanish as a noun to describe an individual (male or female) with what is usually a slightly negative connotation (Conde, 2004). But in the current vernacular of Argentine adolescent and undergraduate speakers, tipo appears to have acquired a more extensive array of language functions, in particular as a pragmatic marker (Huseby, 2010; Kornfeld, 2013). Tipo has also been found to be used as a pragmatic marker in other varieties of Spanish, such as Madrid youth vernacular (Mihastch, 2010; Stenström, 2012), as well as other languages, such as Swedish (Stenström, 2012), Italian and Portuguese (Mihatsch, 2007; Mihastch, 2010). 
Pragmatic markers are single or multi-word expressions that often serve two major functions. In their textual function, they help establish relationships between topics or grammatical units adding to the cohesiveness of discourse; in their interpersonal function, they not only express different speakers' attitudes but also their relationship to or attitude toward the hearer(s) (Brinton, 1996). Some Spanish pragmatic markers have received a fair amount of attention, especially in terms of their use by L1 Spanish speakers, for example pues 'so' (e.g., Martínez García, 1990; Porroche Ballesteros, 1996; Travis, 2005; Stenström, 2006a, b; Vázquez Carranza, 2013) and bueno 'well' (e.g., Fuentes Rodríguez, 1993; Bauhr, 1994; Serrano, 1999; García Vizcaíno and Martínez-Cabeza, 2005; Travis, 2005; Bellés-Fortuño and Fortanet- Gómez, 2009). In comparison, other pragmatic markers have received little attention; examples include two Spanish pragmatic markers with functions similar to those of 'like' in English: como (Jørgensen and Stenström, 2009) and en plan (Stenström, 2012; Jørgensen, 2009) in different varieties of Spanish. Such is also the case of tipo in Argentine Spanish, with what appears to be only one empirical study available to date (Huseby 2010). Like many other pragmatic markers, tipo is functionally complex and has different syntactic functions. Just like other frequent pragmatic markers that are characteristic of the spoken language production of young speakers 
(Jørgensen and Martínez, 2007), its manifold pragmatic functions of tipo remain understudied.

Huseby (2010) examined the discourse functions of tipo in the Corpus Oral de Lenguaje Adolescente de Buenos Aires (Oral Corpus of Adolescent Language from Buenos Aires; COLAba) (Jørgensen, 2007)1. At the time of Huseby's study, COLAba had a total of 50,000 words. Huseby identified 462 uses of tipo as a discourse marker, to which she attributed six functions: to hedge, to approximate, to exemplify, to intensify, to gain processing time (i.e., as a filler), and to mark reported speech. The most prevalent functions in her analysis were hesitation and exemplification marker (with 301 and 114 uses, respectively). Huseby notes that the speakers in COLAba are all middle and higher middle class but she does not report the total number of speakers.

Throughout Huseby's thesis, the illustrative uses for each of these functions come from a group of ten speakers ( 9 females, 1 male). The vast majority of examples, however, come from two female speakers in particular (referred to as Agus and Noelia). In fact, Huseby argues that $98 \%$ of the uses in COLAba are from female speakers, with only 10 recorded uses for a restricted number of functions (filler, approximation, and exemplification) by males in the entire corpus. 
The present study seeks to expand on Huseby's (2010) work by identifying and describing youth-speak meanings of tipo in two different media, face-to-face and technology-mediated communication, in interactions between Spanish speakers of undergraduate age. It also expands the scope of Huseby's work by investigating tipo's functions in interactions between native and nonnative speakers of Spanish (i.e., American undergraduates studying abroad in Argentina). With the addition of an awareness test to the performance data, it also probes expert speakers' understanding of sociopragmatic variability in the use of tipo in Argentine Spanish.

\section{Study methods}

\subsection{Data collection}

This study is based on selected data from a larger investigation of the use of youth vernacular in Argentine Spanish by a group of American and Argentine undergraduate students during the spring of 2012 (Fernández, 2013). The data used for the case study presented here are from ten Argentine undergraduate students aged 18-25.

The participants were instructed to audio-record their interactions with their American conversation partners (same and cross-sex pairings) in four faceto-face interactions (once per month for 4 months). These sessions were each a 
minimum of 30 minutes long plus one weekly text chat session of at least 20 minutes on any technology-mediated platform of their choice, for a total of about 15 sessions spread over the same 4-month period. Their audio-recordings were transcribed using regular orthography. The text chats were cleaned of identifying information (usernames, time stamps, etc.) and collected into a language database for further analysis.

In addition to performance data (i.e., the naturally occurring conversations), this study also tapped into the participants' awareness of the social meaning of tipo at the time of data collection. A modified version of Paribakht and Wesche's (1993) Vocabulary Knowledge Scale (VKS, Figure 1) was used to determine the participants' self-perceived "receptive and initial productive knowledge" (Schmitt, 2010, p. 218) of the youth vernacular uses of the target lexicogrammatical feature. It elicited participants' understanding of its meaning by, for example, asking them to use it in sentences. In addition to the core questions, three additional questions about the constraints on the use of the target lexical features (e.g., in this case, perceived contexts of use, functions in discourse, and level of formality of tipo) were added to the instrument. This additional layer of questioning was used to tap into participants' metapragmatic awareness of the different uses of tipo. The adapted VKS was translated into Spanish from its original, and administered in a paper and pencil format during 
the interview. The participants were allowed to ask questions of the researcher and they were audio recorded as they filled out the VKS.

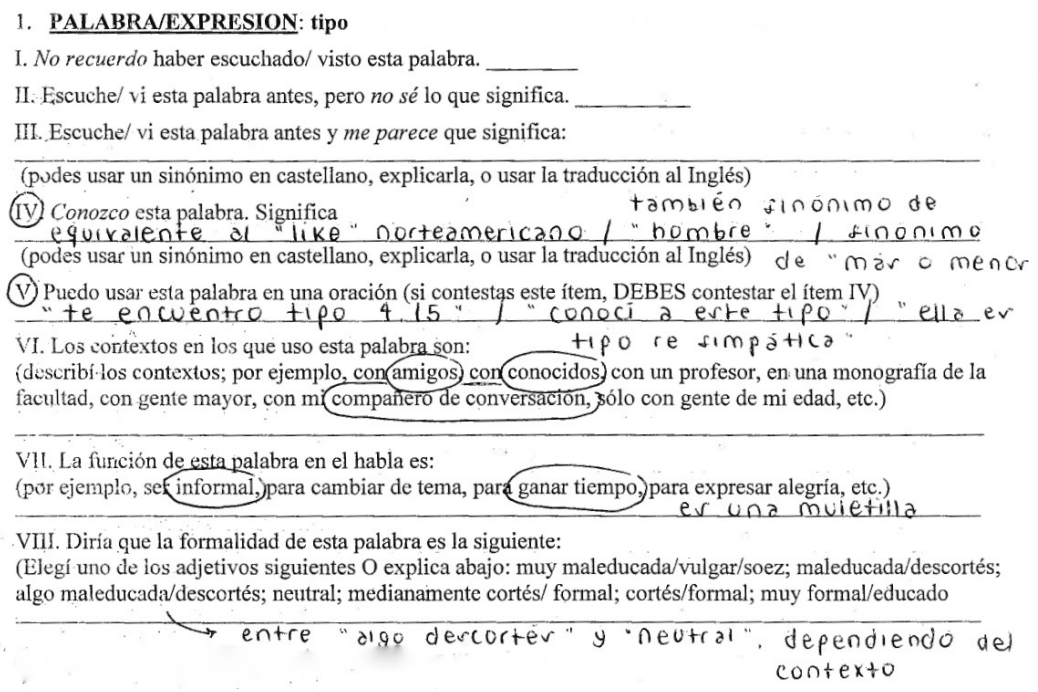

Figure 1. Sample VKS Item (Spanish version) and Sample Participant Response (Jazmín)

\subsection{Participants}

The 10 student participants (Table 1) were majoring in different fields at various universities in downtown Buenos Aires (Ciudad Autónoma de Buenos Aires, CABA). All of the speakers were 18 to 25 years old (a common undergraduate age range in Argentina, which is traditionally 6 years long) and were studying at the university or college level in the city of Buenos Aires at the time of data collection and had spent a minimum of 2 years living and/or studying in CABA. 
Table. 1 Participant demographic information

Pseudonym Gender Age

1. Analía $F \quad 20$

2. Adriana $F \quad 24$

3. Alejandro $M \quad 20$

4. Dalma $\quad F \quad 19$

5. Jazmín $\quad F \quad 19$

6. Mario $M \quad 25$

7. Pablo $M \quad 18$

8. Romina $F \quad 19$

9. Vanesa $F \quad 19$

10. Victoria $F \quad 19$

The participants had various socioeconomic backgrounds ranging from high (Alejandro, Jazmín, Romina, and Vanesa), to higher middle (Pablo), to middle (Adriana), to lower middle class (Analía, Dalma, Mario, and Victoria).

Participants were paired with conversation partners according to their stated list of interests and hobbies (collected through the background questionnaire and an initial interview with the researcher). These conversation partnerships were established primarily as a way for participants to get to know, interact with, and ideally develop a friendship with American undergraduates with similar interests, rather than as a means to act as a Spanish language tutor or to practice L2 English with an English L1 speaker.

\subsection{Analysis}


Occurrences of tipo were retrieved from the dataset using the freeware AntConc (Anthony, 2014). The data set yielded attested uses of tipo with nonpragmatic and pragmatic marking functions. In its non-pragmatic uses, tipo is used to (1) establish a hyponym-general category relationship between two terms (or as a binomial taxonomic noun, cf. Mihatsch, 2016), similar to the English noun type as in "qué tipo de peli te gustan?" ('what tipo of movies do you like?'), (2) make a comparison, similar to the English like as in tipo Venecia ('like Venice'), and (3) to refer to an unspecified man as a noun (similar to 'guy', or 'dude). The first two are documented in general dictionaries of Spanish (e.g., Real Academia Espanola ${ }^{2}$ ) and are used extensively in different written and spoken genres, and thus appear to be the canonical or "sanctioned" (Kinginger and Blattner, 2008) uses of tipo. The use of tipo to refer to a man (with its feminine being tipa), however, is collected by several dictionaries of Argentine slang or lunfardo. Most dictionaries of Argentine slang assign it a pejorative tone (e.g., Conde, 2004) (however, the uses of tipo as a noun in the current database did not seem to carry any negative connotation).

Pragmatic marking uses (textual and interactional) of tipo by each of the participants were identified and are discussed in the results section. Each occurrence was examined within its local and larger context. Only instances of tipo produced by the participants were analyzed, i.e., uses by the L2 Spanish 
speakers were not included in the present analysis. At the micro level, a discourse analytic approach was employed to explore and describe the pragmatic functions of tipo. The functional use categories discerned from the data were compared and contrasted with those found in the literature for tipo (Huseby, 2010) and the English pragmatic marker like (Andersen, 2001; Meehan, 1991; Underhill, 1988). Also, given the sampling method employed and the small sample size, the data were analyzed qualitatively; that is, they have not been analyzed for frequency of use by speaker, gender, and/or socioeconomic status.

The qualitative responses to the last five items in the modified VKS (i.e., meaning, sample sentence(s), perceived contexts of use, functions in discourse, and level of formality) were collated and analyzed.

4. Results

The data provide a description of the pragmatic uses of tipo based on 142 uses in attested interactions between the participants and L2 learners. Given the paucity of studies on the use of tipo in Argentine Spanish youth vernacular, a description of each function is provided together with several examples from the one-on-one interactions between the participants and their conversation partners.

In the interactional data, the participants were found to most frequently use tipo with a pragmatic marking function, and to a lesser extent as a noun to 
describe a man, to introduce a hyponym, or to make a comparison, as described in detail in each of the sections below.

\subsection{Hesitation}

Tipo was used very often as a hesitation device, and was seen as an indicator that the speaker needed time to think or to perform a word search. In excerpt 1 , Alejandro's phonological prolongation of the final /o/ in tipo is followed by a short silence plus eh, the most common Spanish "filler" (Cenoz, 1998), which is also prolonged (line 6). The use of tipo, as well as the pause filled with the vocalization eh, appears to be a way to continue to hold the floor while searching for the most appropriate word in context (lines 6-7). Alejandro seems to be searching for the best descriptor for the type of tourism activities that he believes Erin wants to engage in. He first offers the adjective tranquilo ('relaxed' or 'calm'; line 6), and then settles for sedentario ('sedentary'; line 7).

Excerpt 1. Tipo as hesitation device (Alejandro and Erin)

$1<\mathrm{E}>$ hicimos lugares turísticos

2 (xx) muchísimos, de museos no

3 de pero uno de la Boca, de

4 Puerto Madero de cre-, de digo Plaza de Mayo así.

$5 \quad<$ A si vos querés hacer mini

6 turismo tipo: e:h más tranquilo

7 más este: sedentario we did many touristic places $(x x x)$ a lot, of museums not of but one in La Boca, in Puerto Madero, in cre-, in I mean Plaza de Mayo like this.

if you want to do mini tourism tipo: $\mathrm{u}: \mathrm{h}$ more relaxed more $\mathrm{u}: \mathrm{hm}$ sedentary 
In the next example, Analía is describing to Kaelyn the types of classroom activities she often conducts. In trying to find the best way to describe an activity in which the students take turns throwing dice and moving spaces on a board laid out on the floor (where there are review cards for them to pick up), Analía uses tipo with a prolonged final /o/ in between a repeated coordinating conjunction (line 6).

Excerpt 2. Tipo as hesitation device (Analía and Kaelyn)

$1 \quad<$ A $>$ así con cosas que para repasary like with things that to review and well 2 bueno

$3<\mathrm{K}>$ una pregunta o algo a question or something

$4<$ A claro right

$5<\mathrm{K}>$ uh uh

6 <A> y tipo: $y$ si no me retroceden un and tipo: and otherwise they go back a

7 casillero $y$ esas cosas space and things like that

In excerpt 3, Vanesa is explaining a linguistic phenomenon she has observed in Argentine Spanish, in which certain English words are borrowed and adapted into Spanish phonology. Their spelling is normalized and they are further adapted by adding the Spanish verbal ending -ar (lines 1-3; Escobar and Potowski, 2015). She provides Google and the verb guglear as an example (line 4) and produces a tipo (also with a prolongation of the final /o/) at the end of her utterance (line 4). 
Excerpt 3. Tipo as a hesitation device (Vanesa and Paul)

$1<\mathrm{V}>$ Acá se hace mucho eso agarrar

2 u::n una palabra en inglés? $Y$

3 convertirlo en eh en verbo como

4 guglear por ejemplo en vez de buscar en Google se dice guglear tipo:

$5<\mathrm{P}>$ si

$6 \quad<$ V> sí, vas a ver mucho de eso here we do that a lot to take a: a word in English? And make it into eh into a verb like googlear for example instead of to look up in Google you say googlear tipo:

yes

yes, you are going to see a lot of that

Another participant, Pablo, uses tipo (excerpt 4, line 4) on its own as he appears to be thinking of ways to continue with the interaction, which by that point seemed rather drawn out and topics of conversation seemed slightly forced.

Excerpt 4. Tipo as hesitation device (Pablo and Sally)

$1<\mathrm{P}>$ te gusta más cursar a la mañana o what do you like best to take classes in the

2 a la tarde? morning or in the afternoon?

$3<$ S $>$ al mediodía [risa]

$4<\mathrm{P}>$ tipo: at noon [laughter]

$5<\mathrm{S}>$ me gusta $u: m$, once, entre las las tipo:

6 once y las u::m dieciséis. Y tú en la mañana?

$7 \quad$ < $>$ sí en la mañana sí I like $\mathrm{u}: \mathrm{m}$ eleven [am] between eleven and $\mathrm{u}:$ :m four pm. And you in the morning? yes, in the morning yes

\subsection{Exemplification}

When used to exemplify, tipo can be paraphrased as 'for example'. The examples introduced often specify a more general concept or noun. In excerpt 5, for example, when Molly describes the artistic activities of her host family, she 
mentions that one of the host daughters can dance (lines 4 and 6). In the following turn, Romina first repeats the hypernym or superordinate noun dance and uses tipo to introduce two sample hyponyms to request that Molly narrow down the specific dance form(s) she is referring to (line 7).

Excerpt 5. Tipo for exemplification (Molly and Romina)

$1<\mathrm{M}>$ sí. $y$ : eh, la familia es $u: h$, me

2 gustar te mucho aaar mucha, u:hm, la

3 madre puede: actar y: u:h canta:r y

4 u:hm, las hermanas u:hm, u:h una hermana: baile

$5<\mathrm{R}>$ uh-huh.

$6<\mathrm{M}>$ baile y: la otra [.] le gusta [.]

$7<\mathrm{R}>$ ¿baile tipo ballet? o ¿tango?

$8<\mathrm{M}>$ u:hm, clásico: $y$ tap yes. a:nd eh, the family is $u: h, I$ to like you a lot [masc.] aaar a lot [fem.], the mother ca:n act a:nd u:h si:ng and $u: h m$, the sisters $\mathrm{u}: \mathrm{hm}, \mathrm{u}: \mathrm{h}$ one siste:r dance [noun]

uh-huh. dance a:nd the other [.] she likes [.] dance tipo ballet? or tango? $\mathrm{u}: \mathrm{hm}$, classical and tap

Excerpt 6 is taken from Pablo's and Sally's third meeting, to which Pablo had brought his Argentine friend and classmate Felicia. Here, Pablo and Felicia are discussing expressions that would be essential for Sally to know in order to get by in Argentina. In trying to understand what Pablo means by the "most basic" expressions (line 2), Felicia asks for more specification (line 3). Pablo then uses tipo to introduce sample expressions that might be of use (lines 4-5).

Excerpt 6. Tipo for exemplification (Pablo, Felicia, and Sally)

$1<\mathrm{F}>$ ¿Cuáles son esenciales? Which ones are essential?

$2<\mathrm{P}>$ ¿Esenciales? Las más básicas, 
$3<\mathrm{F}>$ ¿A ver cómo cuáles?

$4<\mathrm{P}>$ tipo por favor, gracias, hola, ¿cómo

5 estás?
Let's see which ones?

tipo please, thank you, hello, how are you?

\subsection{Reformulation}

The interactions also provided many examples of tipo used as a reformulation device. Tipo was used to reword, paraphrase, elaborate, or explain information, with the intent of clarifying, specifying, or expanding a point (Aijmer, 2007). In excerpt 7 , Vanesa is describing to Paul a common nightlife practice among undergraduates in Argentina (lines 5-6). She provides the youth vernacular term for this social practice, el bajón (line 6), and then uses tipo after the copula in an adjectival clause seemingly to unpack the meaning of this expression for Paul's sake (lines 8-10), although Paul's uh in line 7 does not unequivocally indicate that he does not know or understand the expression.

\section{Excerpt 7. Tipo for reformulation (Vanesa and Paul)}

$1<\mathrm{V}>$ acá por lo general lo que se hace

2 es [.] vos haces una salida? A la noche,

3 salís a un boliche todo

$4<\mathrm{P}>$ sí sí

$5 \quad<\mathrm{V}>$ y a las seis de la mañana haces lo

6 que se llama el bajón

$7 \quad<\mathrm{P}>$ uh

$8<\mathrm{V}>$ que es tipo el así vas y comés a

9 las seis de la mañana una

10 hamburguesa y después se van todos a

11 su casa a dormir

here in general what you do is [.] you go out? At night, you go to a night club all yes yes and at six in the morning you do what we call the bajón

uh that is tipo the like you go eat at six in the morning a hamburger and then they all go home to sleep 
In several of its reformulation uses, the participants (particularly those who spoke fluent English) code-switched into English. In excerpt 8, for example, Romina introduces a type of photography called HDR (line 1), explains what the acronym stands for (lines 1-2), and then elaborates upon what this digital imaging technique involves (such as taking five pictures with different exposures; lines 4-6). Romina then uses tipo (line 6) to introduce a reformulation of the word exposición ('exposure'; lines 7-8), which is a fairly technical term. Here, Romina provides an explanation or a translation of a term to aid Molly's understanding (as in the case of a low-frequency and fairly specialized lexical item such as exposure in the context of photography) and/or move the interaction along.

Excerpt 8. Tipo for reformulation (Molly and Romina)

$1<\mathrm{R}>$ HDR que e:h, es high dynamic

2 range, creo

$3<\mathrm{M}>$ all right

$4 \quad<\mathrm{R}>$ que es como, está buena, es

5 como que sacás de una misma cosa

6 como cinco fotos con diferente como

7 exposición tipo el shutter time lo vas cambiando
HDR that e:h, is high dynamic range, I think all right that is like, it's great, it's like you take of the same thing like five pictures with different like exposure tipo you change the shutter time

Reinforcing tipo's reformulating function, speakers oftentimes used it in combination with (i.e., immediately preceded or followed by) the pragmatic marker $o$ sea, which translates as 'that is (to say)'. As a case in point, in excerpt 9, Vanesa uses the term guachos (line 1). Paul offers a candidate hearing, 
baches (line 2), indicating to Vanesa that he did not know this word. She thus repeats the word (line 2) and then uses tipo followed by o sea to introduce a reformulation or explanation of the term. In this explanation, she uses tipo three more times, twice to introduce English translations for the two possible meanings of the word (line 5), until Paul gives indication that he has understood it (line 7). Excerpt 9. Tipo for reformulation (Vanesa and Paul)

$1<\mathrm{V}>$ Qué guachos!

$2<\mathrm{P}>$ sí [.] qué baches?

$3<$ V > Guacho tipo: [.] tsck o sea [.]

4 guacho can be it can be negative like

5 uhm tipo a bad person o guacho tipo

6 you lucky bugger [xxx] tipo:

$7 \quad<\mathrm{P}>$ Ah sí, claro
Such bastards!

yes [.] what potholes?

Guacho tipo: [.] tsck that is [.] guacho can be it can be negative like uhm tipo a bad person or guacho tipo you lucky bugger [xxx] tipo:

Oh yes, right

\subsection{Vagueness}

When used as a vagueness marker (for approximation or hedging), tipo is often placed before a quantitative noun (phrase), usually a number representing a time of the day, rendering the quantity to which the number refers less precise. This appears to be done to provide for some flexibility, particularly when it comes to arranging times to meet, for example, as shown in excerpt 10 , which is a portion of a Facebook exchange between Dalma and Kelly when they were arranging a time to meet. Because Dalma had to take public transportation to get to their meeting place from work (which, though frequent, was often unreliable in the city due to traffic), she suggested meeting "tipo five," allowing some flexibility 
in case she did not make it on the dot. In this case, tipo appears to have a function similar to that of the hedge around, added to numerical expressions in order to make them less precise, or the suffixes -like and -ish used in colloquial English (Cheng and Warren, 2003; Mihatsch, 2007).

Excerpt 10. Tipo for approximation (Dalma and Kelly, technology mediated)

$1<\mathrm{D}>$ hola gordi. yo hoy no podía. podés hello sweetie. today I wasn't available. can

2 el miércoles? you [meet] on Wednesday?

$3<\mathrm{K}>$ si! yes!

$4<\mathrm{D}>$ tipo 5 dale? $x q$ salgo del instituto $y$ tipo 5 okay? 'cause I finish at the institute

5 voy para once and I leave for Once [name of a neighborhood]

$6<\mathrm{K}>$ bueno! okay!

Tipo was also used as a hedging device when the speaker appeared unsure or did not want to fully commit to the truth or accuracy of her statement. In excerpt 11 , Analía is very vaguely referring to a piece she had seen on the news about Kaelyn's home state in the United States. She uses the pragmatic marker tipo to hedge the fact that the news was about championships. It appears that she does not want to commit to the truth of that statement. Her lack of commitment is further reinforced by the use of the question puede ser? ('can it be?') twice (lines 2-3 and 6), the vague markers algo ('something'; line 5) and algo asi ('something like that'; line 6; Fernández, 2015), and the expression no me acuerdo ('I don't remember'; line 5). 
Excerpt 11. Tipo for approximation (Analía and Kaelyn)

$1<\mathrm{A}>$ el otro día estaba viendo que era

2 una noticia de Pennsylvania puede

3 ser?

$4 \quad<\mathrm{K}>s-$ ah pued-bueno, de qué?

$5<\mathrm{A}>$ y no me acuerdo algo de tipo

6 campeonatos o puede ser algo así ?

7 después te lo paso

$8<\mathrm{K}>$ okay the other day I was watching what was news from Pennsylvania can it be?

$y$ - uh it ca- well, about what?

I don't remember something about tipo championships or can it be something like that? later l'll send it to you okay

\subsection{Quoted speech}

Vanesa and Jazmín produced several instances of tipo with a quotative function. Its position was fixed "before an embedded clause which is interpreted as a quote" (Meehan, 1991:46). As shown in excerpts 12 (lines 1 and 7) and 13 (line 5), in this function tipo can be immediately preceded by the copula. The construction frequently used by the speakers was "(it) is/was tipo + quote." In 12, Vanesa is retelling her first experience visiting the Grand Canyon. She uses tipo twice, both times preceded by the verb ser (to be), first in present tense (line 1) and then in past tense (line 7).

\section{Excerpt 12. Tipo as quotative (Vanesa and Paul)}

$1 \quad<\mathrm{V}>$ la verdad llegás y es tipo jwow

2 son enormes!

$3<\mathrm{P}>$ sí

$4 \quad<\mathrm{V}>$ es algo que no, tenés que ir a

5 verlo

[...]

$6 \quad<\mathrm{V}>$ no, yo llegué al Grand Canyon y and the truth is you arrive and it's tipo wow they are huge! yes it is something that no, you have to go and see it

no, I arrived at the Grand Canyon and 
$7 \quad$ fue tipo wow soy muy chiquita, soy un

8 organismo muy pequeño it was tipo wow l'm very small I'm a very small organism

In excerpt 13, Jazmín uses tipo twice to introduce "paradigmatic exemplars" or statements "similar in form and content" which "might have been produced in the circumstance in question" (Fleischman and Yaguello, 2004: 140). In this case, Jazmín is referring to typical greetings she has repeatedly heard from cashiers at stores in the United States (lines 4 and 5). In this instance, she clearly does not have a particular speaker or quote in mind, but rather a speech act that she deems recurrent (and thus superfluous or devoid of any real meaning). Here again, the construction "(it) is/was tipo + quote" is used for introducing 'paradigmatic' quoted speech.

Excerpt 13. Tipo as quotative (Jazmín and Harry)

$1<\mathrm{J}>$ es como que te saludan [.] siempre it's like they greet you [.] it's always that 2 está la cosa en Estados Unidos me di thing in the United States I realized that

3 cuenta es como que no sé vos pagas [it's] like you pay for something in the

4 algo en un supermercado y siempre supermarket and it's always tipo have a

5 es tipo" have a nice day!" O tipo "hi, nice day! or tipo hi how is it going? but

6 how is it going?" pero te lo preguntan they ask you this like automatically

7 como automático

$8<\mathrm{H}>$ yeah yeah

Tipo can also be used to introduce a direct quote and follow a verb of saying (though not always immediately preceding it, as seen in line 2), such as 
decir ('say/tell') in excerpt 14. In this case, Vanesa is retelling her expressions of disbelief when she found out that her father was invited to a popular concert and he did not had to pay entrance.

Excerpt 14. Tipo as quotative (Vanesa and Paul)

$1<$ V > y no tuvo que pagar tipo lo

2 invitaron, yo le dije "sos un guacho",

3 tipo "me estas j-" tipo me estas cargando

$4 \quad<\mathrm{P}>$ sí and he didn't have to pay tipo he was invited, and I told him "you're a [lucky] bastard", tipo "you are sh-" tipo you are pulling my leg

yes

Tipo appeared to also be used for dramatic effect (Meehan, 1991), as in excerpt 15. This is a 'hypothetical' quote (dramatizing different possible utterances) (Jones and Schieffelin, 2009) introduced by tipo, with no verb of saying. Vanesa is demonstrating the types of questions that Paul can ask her if he does not understand her (lines 3-4).

Excerpt 15. Tipo as quotative (Vanesa and Paul)

$1<\mathrm{V}>$ no te preocupes, en serio. Cualquier

2 cosa interrumpime. No tengas miedo,

3 tipo "qué es eso?" "Qué me estás

4 diciendo?" "No te entiendo"

$5<\mathrm{P}>$ uh okay

$6<\mathrm{V}>$ y yo te lo explico. No tengo

7 problema don't worry, I mean it. For anything interrupt me. Don't be afraid. Tipo what is that? What are you telling me? I don't understand you

uh okay and I explain it to you. I have no problem 
Jazmín (excerpt 16) also used tipo to introduce a hypothetical quote when discussing the types of questions she wished she would be asked in a particular high-stakes test of English proficiency (lines 3-4).

Excerpt 16. Tipo as quotative (Jazmín and Henry)

$1<\mathrm{J}>$ no sé, es un, nunca te van a

2 preguntar algo importante. No te van a

3 preguntar tipo no sé, "what is your

4 opinion about the foreign policies of your country?" [se ríe]

$5<\mathrm{H}>$ yeah, porque algunos tienen que

6 probar que podés hablar no de qué
I don't know, it's a, they are never going to ask you something important. They are not going to ask you tipo I don't know "what is your opinion about the foreign policies of your country?" [laughs] yeah, because some have to prove that you can talk not about what

Several patterns appear to emerge in these examples. In excerpt 12, Vanesa uses the impersonal second person singular in the present tense, with the verb ending for vos ('you') as used in Argentine Spanish, to paradigmatically refer to anybody who arrives at the Grand Canyon. She then proceeds to introduce the paradigmatic quote she assumes would be everybody's reaction upon gazing on it for the first time (lines 1-2). When she switches to her own experience (lines 6-8), she uses past tense to introduce the quote (i.e., in the construction fue tipo $x$ ). In this case, the quote introduced by tipo appears to mark her "internal thought" trying to take in such a majestic view for the first time rather than the report of an utterance "actually spoken aloud" (Dailey-O'Cain, 2000:66). 
A similar paradigmatic quote is used in excerpt 13 , when Jazmín introduces a prototypical greeting at a store in the United States with the 'to be' + tipo construction in the present tense. The fact that this is not an actual quote is strengthened by the use of the frequency adverb siempre ('always'), siempre es tipo + quote. Jazmín also uses tipo to introduce a hypothetical quote (though not immediately preceding the quote) together with the frequency adverb nunca ('never') in excerpt 16, although in this case she does not use the copula, but rather the verb of saying preguntar ('to ask') in the present tense.

Finally, Vanesa also uses tipo to introduce a hypothetical quote when she lists all the questions that Paul can ask her (excerpt 15), although in this case there is also no copula or verb of saying (though it can be hypothesized that if it had not been omitted, given that the rest of the utterance is in present tense, the verb would be in present tense as well). In contrast, when preceded by a verb in the past tense, then tipo appears to introduce a direct quote (as shown in excerpt 14). The quote, however, is often not to be taken literally. As argued by Huseby (2010), when used as a quotative, tipo retains some of its approximating value.

\subsection{Expert-speaker information about the social meanings of tipo}

In the language awareness test, participants assigned tipo several language functions. The five functions they identified are discussed in order of 
frequency of mention in the VKS responses to questions IV 'I know this word. It means...', V 'I can use this word in a sentence', and VII 'the function of this word in speech is.' As will become evident, and unsurprisingly for a pragmatic marker of this kind, the participants assigned tipo more than one language function.

Table 2. VKS responses to Item IV

\begin{tabular}{|c|c|}
\hline Participant & Examples \\
\hline \multirow[t]{2}{*}{ 1. Analía } & Nos encontramos tipo 8. \\
\hline & We met/Let's meet tipo 8 . \\
\hline 2. Adriana & $\begin{array}{l}\text { Es como tipo re inteligente esa chica. } \\
\text { It's like tipo super intelligent, that girl. }\end{array}$ \\
\hline \multirow[t]{2}{*}{ 3. Alejandro } & Y sí tipo 8 o 9 éramos. \\
\hline & And yes we were tipo 8 or 9 \\
\hline \multirow[t]{2}{*}{ 4. Dalma } & $\begin{array}{l}\text { Pensé que estabas cocinando así tipo con una } \\
\text { cuchara. }\end{array}$ \\
\hline & $\begin{array}{l}\text { I thought that you were cooking like tipo with a } \\
\text { spoon. }\end{array}$ \\
\hline \multirow[t]{6}{*}{ 5. Jazmín } & Te encuentro tipo 4.15 \\
\hline & I'll meet you tipo 4.15 . \\
\hline & Conocí a este tipo. \\
\hline & I met this tipo. \\
\hline & Ella es tipo re simpática. \\
\hline & She is tipo super nice. \\
\hline \multirow[t]{2}{*}{ 6. Mario } & Tipo un gobierno de derecha pero no lo es. \\
\hline & Tipo it's a right-wing government but it is not. \\
\hline \multirow[t]{2}{*}{ 7. Pablo } & Tenía una bici que era tipo de carrera. \\
\hline & I had a bicycle that was tipo a racing bicycle. \\
\hline \multirow[t]{2}{*}{ 8. Romina } & Voy para tu casa tipo cinco. \\
\hline & I'll come to your place tipo five. \\
\hline \multirow[t]{4}{*}{ 9. Vanesa } & Este es un ejemplo del tipo práctico; \\
\hline & This is an example of the practical tipo. \\
\hline & La palabra tipo es tipo una muletilla. \\
\hline & The word tipo is tipo a filler. \\
\hline \multirow[t]{2}{*}{ 10. Victoria } & $\begin{array}{l}\text { Donde fuimos el sábado era tipo el bar de la } \\
\text { semana pasada. }\end{array}$ \\
\hline & The place we went to last Saturday was tipo the \\
\hline
\end{tabular}


bar from last week.

Five participants (Analía, Adriana, Jazmín, Romina and Vanesa) assigned tipo a filler function referring to it as 'una muletilla' (literally, a small 'crutch' used metaphorically to refer to an expression that interactants 'lean on' when speaking). Three more (Alejandro, Pablo and Victoria) also assigned it filler function by noting that it is used "to buy time" in conversation. Adriana specifically noted that it is a filler de moda "in fashion," or popular at the moment of data collection, while Vanesa argued that it is a "moda lingüística" 'linguistic fashion' that started about ten years ago and is now established in the discourse of young speakers. Analía, in turn, circumscribed its use as a filler to Ciudad Autónoma de Buenos Aires 'downtown Buenos Aires.' Overall, this was by far the function with which the participants associated tipo most frequently in the language awareness test.

Next, six participants (Analía, Adriana, Alejandro, Dalma, Mario and Victoria) assigned tipo primarily a comparative function - that is, comparing and contrasting two things that are similar or one thing that is like the other (algo parecido 'something similar' or es como (que) '[it] is as if/ like'). This use appears to be close to tipo's original meaning ('a type of') and is exemplified in Mario's example (Table 2): '[lt] is tipo a right wing government but it isn't.' 
Two participants (Analía and Jazmín) associated the use of tipo with approximation (Analía explicitly equating it with aproximadamente 'approximately' and Jazmín with the expression más o menos 'more or less'). However, under other functions (namely, as filler, marking exemplification, or showing similarity), Alejandro and Romina also provided examples of its use for approximation (Table 2).

One of the participants, Vanesa, equated the meaning of tipo to that of $o$ sea but referred to both pragmatic markers as fillers to be avoided in formal situations (such as talking to a professor), rather than focusing on identifying their reformulating functions. One the other hand, Romina assigned it the function of introducing examples, but she did not provide an illustration of this meaning among her examples.

Two of the participants (Jazmín and Vanesa) noted that tipo is the equivalent of the American like. However, they did not identify which one(s) of the many potential meanings of like (see Andersen, 2001) they had in mind, or if they would all be overlapping. These were the two participants who used tipo as a quotation marker. It could thus be argued that they might have had like's quotative function in mind.

Another participant, Pablo, responded that tipo had the sole meaning of denoting 'a class of' (i.e., un tipo de 'a type of' introducing a hyponym) in youth 
vernacular. His example, however, was ambiguous. His sentence read 'tenía una bici que era tipo de carrera' '[l/he/she] had a bike that was tipo for racing.' A racing bicycle ('una bici de carrera) is a type of bicycle. However, he did not use tipo in a hyponym construction, such as un tipo de (bicicleta) 'a type of (bicycle).' As a result, the sentence could also be interpreted as indicating similarity, i.e. a bicycle that looked like for racing. Vanesa stated that it denotes 'a category of something,' (exemplified in her sentence 'Este es un ejemplo del tipo práctico'), but both in written and oral form stated that this was its formal or canonical use.

Table 3. Contexts of use and level of formality of tipo

\begin{tabular}{|c|c|c|}
\hline Participant & $\begin{array}{l}\text { Contexts in which l'd use this } \\
\text { word: }\end{array}$ & $\begin{array}{l}\text { l'd say the level of formality of } \\
\text { this word is: }\end{array}$ \\
\hline 1. Analía & With friends and family & It's informal \\
\hline 2. Adriana & $\begin{array}{l}\text { Only with friends and people } \\
\text { I know well. }\end{array}$ & It's vulgar \\
\hline 3. & With my family, when & Impolite, informal, but it \\
\hline Alejandro & $\begin{array}{l}\text { hanging out with friends or } \\
\text { people I know; with } \\
\text { professors or people from } \\
\text { other ages }\end{array}$ & $\begin{array}{l}\text { doesn't imply that you are } \\
\text { disrespecting (the interlocutor) }\end{array}$ \\
\hline 4. Dalma & l'd use it with everybody & $\begin{array}{l}\text { It's neutral (nor impolite nor } \\
\text { polite) }\end{array}$ \\
\hline 5. Jazmín & $\begin{array}{l}\text { With friends, people I know, } \\
\text { and conversation partners. }\end{array}$ & $\begin{array}{l}\text { It's in between somewhat } \\
\text { impolite and neutral depending } \\
\text { on the context. }\end{array}$ \\
\hline 6. Mario & With everybody & It's neutral \\
\hline 7. Pablo & With friends only & It's informal \\
\hline 8. Romina & $\begin{array}{l}\text { With everybody although we } \\
\text { shouldn't use it in a } \\
\text { professional context (but it is } \\
\text { difficult to avoid) }\end{array}$ & It's both neutral and informal. \\
\hline
\end{tabular}




\begin{tabular}{lll} 
9. Vanesa & I wouldn't use it in a formal \\
context, like with a professor. & $\begin{array}{l}\text { It's both neutral and informal } \\
\text { (it's not offensive or vulgar, }\end{array}$ \\
& $\begin{array}{l}\text { l'd use it with friends and } \\
\text { people I know. }\end{array}$ & $\begin{array}{l}\text { l've heard it in formal contexts, } \\
\text { though I wouldn't use it). }\end{array}$ \\
$\begin{array}{l}\text { 10. Victoria } \\
\text { With friends, people I know, } \\
\text { professors, my conversation } \\
\text { partner. }\end{array}$ & It's neutral \\
\hline
\end{tabular}

The participants appeared evenly divided as to whether tipo would be appropriate in any context (formal or informal) (Alejandro, Dalma, Mario, Romina and Victoria) or only in an informal context (Analia, Adriana, Jazmin, Pablo, and Vanesa).

The participants orally expressed that tipo is very frequent in spoken language (especially when speaking with their peers). However, they argued that they themselves either did not use it at all or that, when they did, they could not help it and would have really liked to stop doing so. For example, Romina argued that 'we shouldn't use it' in a formal or professional context. Vanesa added that in a formal context it should not be used to "hacer tiempo porque quita claridad" ("that is, it should not be used as a filler because it obfuscates meaning") but in an informal context she would not only use it but hear it all the time. Analía (excerpt 17) argued that while her classmates used tipo all the time (lines 4-5), she did not use it at all with this pragmatic marking function (line 6), and that she was not able to provide a good example (7). 
Excerpt 17. Analía's opinion about tipo (Analía, interview 3)

1 A: Yo quiero poner que [tipo]

2 significa "es como" (.5) sí se usa

3 mucho, encima, pero justo en el

4 momento no me sale (.10) ay la

5 usan todo el tiempo en mi facultad

6 encima para todo ahora se me

7 nubló. e::hm (.7) bueno yo no la uso así pero (.5) malísimo el ejemplo.
A: I want to write that [tipo] means "[it] is like" (.5), yes it is used a lot, on top of that, but right now I cannot think of anything (.10) on top of that they use it all the time in my university and now it's all hazy. u::hm (.7) well I don't use it like this but (.5) very bad my example.

Another case in point is Jazmín's distaste for the use of tipo (line 8), which she qualifies as something 'very personal' (lines $4 \& 15$ ) but does appear to be rather consistent across participants. Although she expressed that she was bothered by it and would not want people to use it all the time (as her friends do), she admitted that she just "pick[ed] it up" (line 7) and could not help but use it (lines 4-5; 7-8).

Excerpt 18. Jazmín's opinion about tipo (Jazmín, interview 3)

$1 \mathrm{~J}:$ [se ríe] (.3) y justo con lo de: tipo

2 contesté como que era neutral pero

3 tirando a descortés pero por una

4 cuestión mía de que tengo amigas

5 que lo usan sie:mpre

6 Re: sí

7 J: y a mí también se me pega pero

8 me molesta es como que

9 Re: okay

$10 \mathrm{~J}$ : lo tengo como no sé algo medio

11 Re: [se ríe]

$12 \mathrm{~J}$ : como que no me gustaría que
J: [laughs] (.3) and about tipo I answered like it is neutral but leaning to impolite but that's my issue because I have (female) friends that use it all the time Re: yes $\mathrm{J}$ : and I pick it up too [literally: it sticks to me too] but it bothers me it's like Re: okay J: I have it like I don't know something kind of Re: [laughs] J: like I wouldn't want that somebody 
13 alguien me hable y siempre lo use

14 Re: está bien

$15 \mathrm{~J}$ : muy personal eso talk to me and use it all the time Re: all right

$\mathrm{J}$ : that (is) very personal

Finally, as regards its level of formality, five participants stated that it is neutral (Dalma, Mario, Romina, Vanesa and Victoria), five participants identified it as informal (Analía, Alejandro, Pablo, Romina and Vanesa), and in a more nuanced answer one participant, Jazmín, specified that whether it is informal or neutral depends on the context. Alejandro also further clarified that while it can be impolite, it does not involve disrespect for the interlocutor. Only Adriana identified it as vulgar.

\section{Discussion}

This analysis demonstrates that tipo is a functionally complex pragmatic marker with flexible distribution. As regards function, it was found to signal hesitation (e.g., excerpt 1), introduce an example (e.g., excerpt 5), mark vagueness (e.g., excerpt 10), preface an explanation or reformulation (e.g., excerpt 7), or introduce a quote (e.g., excerpt 13). In terms of distributional properties, and as illustrated in the excerpts included in this paper, it occurred between propositions or utterances, at the end of utterances, as a separate 
utterance, within phrases, between clause constituents, and as part of the construction "(it) is/was tipo + quote."

In Peninsular Spanish and other languages (French, Italian, and Portuguese), the uses of tipo as an approximator have been shown to have followed a path of pragmaticalization (Mihatsch, 2007). Based on the present results, it appears that in the vernacular of this group of young speakers tipo has undergone a process of grammaticalization that has resulted in a variety of nonpropositional uses (cf. Kornfeld, 2013). However, no claims can be made as to its complete exclusivity to youngspeak or its stage in a process of grammaticalization (or pragmaticalization) given that a comparable data set of adult speakers was not collected for the same time period (Andersen, 2001). Therefore, it cannot be established that Argentine young speakers use tipo more frequently and for a wider range of functions than adult Argentine Spanish speakers (Foolen, 2012).

The functions of tipo described here are based on its use in interactions between L1 speakers of Argentine Spanish and American L2 Spanish learners. It is possible that these functions may not extend to interactions among expert or native speakers of the language, especially the reformulating function of tipo (not documented as a separate function, for example, by Huseby, 2010). The functions of tipo reported here should be considered preliminary yet indicative of 
patterns in Argentine youth vernacular and as a direction for further inquiry. Notwithstanding these limitations, this study begins to address some of the gaps in the area of pragmatic marker use among Argentine youth speakers, and in particular, the paucity of empirical descriptions of the use of tipo.

The medium of communication (face-to-face vs. technology-mediated discourse) seemed to have an effect on the frequency of use and functions of tipo. The participants used tipo in their technology-mediated interactions much less than in their face-to-face interactions. Online, tipo was used mainly as a vagueness marker (approximation) - e.g., tipo mediodía (tipo noon), and to a much lesser degree for reformulation—e.g., Hongos. Sí, tipo moho ('Fungi. Yes, tipo mold'). No uses for hesitation, exemplification or quoted speech were found in the technology-mediated interactions.

Fox Tree (2010) argues that because instant messaging is spontaneous and speakers treat it as "conversation" the use of pragmatic markers is frequent, particularly when the interlocutors are "experts" in the domain, which would be the case with the undergraduate population here, known for their frequent use of Facebook. She points out, however, that spoken interactions have a higher rate of pragmatic marker use than instant messaging (IM). She attributes this difference to "the relative costs of typing a discourse marker versus saying one" (p. 277). 
Whereas Fox Tree (2010) mentions the minimal amount of time that the interactants have to revise their text as they are chatting on IM, in this study one of the reasons behind the lower proportional preferences for the use of tipo in the online environment might lie in speakers' prescriptive attitudes towards these types of spoken pragmatic markers (Dailey O'Cain, 2000), often looked down upon as muletillas. In the language awareness data, most participants characterized tipo first and foremost as a "filler" that they "could not avoid" in speech, implying that they attached a negative value to it.

In terms of the identified functions, "evincive" (Schourup, 1985) uses of tipo (i.e., uses indicating that the speaker is processing information before proceeding) co-occurred with prolongations and repetitions, particularly of function words (excerpt 3), which are common hesitation strategies in spontaneous speech (Pillai, 2006). These hesitation marking uses of tipo can be considered part of interactional strategies related to turn-taking management, which allow the speakers to hold their turn, signaling to the listener(s) that this is not a transition relevance place (excerpt 2). At the same time, tipo can also be strategically deployed to signal to the listener that the speaker is "giving up" (Stenström, 2014:80), that is, the speaker realizes that she has nothing else to add and thus yields the turn (excerpt 5). 
At the interpersonal level, the use of tipo for approximation and hedging (vagueness) can be viewed as a politeness strategy that speakers draw on when trying to save face or intending to leave the door open for possible alternatives. In this case, it can be argued that tipo, much like the pragmatic marker like, can be used for politeness purposes by serving as "a tool for not sounding too assertive" and allowing the speakers to express themselves "with a tentative attitude" (Andersen, 2001:229).

Tipo was also used as a device for introducing quoted speech. The patterns that emerge from the data indicate that when used with the copula (in the construction es tipo $x$ ) or a verb of saying (such as preguntar, to ask) in present tense tipo introduces either a paradigmatic or a hypothetical quote. When the verb 'to be' or verb of saying is in the past, tipo appears to introduce a direct quote that represents internal thought or not to be taken literally. These findings are preliminary, given that this was the least frequently used function in the current data, which falls in line with Huseby's (2010) findings (this was one of the two least frequently used functions in her study, together with approximation).

At the discourse level, tipo was used to introduce an example, as well as a reformulation (in the form of a paraphrase, elaboration, or specification). Its uses to clarify or expand a point, together with its frequent association with the reformulation marker o sea (that is, in other words), indicate that tipo is a 
"paraphrastic" reformulation marker, which expands the semantic content without altering it (Aijmer, 2007). Huseby (2010) did not identify reformulation as a separate function in her study. However, a few of the examples from COLAba that she discusses in the sections on exemplification and at least one of the examples for intensification (excerpt 21, p. 54) (which is immediately preceded by $o$ sea), have a function in discourse that would be considered reformulation in this study. In addition, there are a few more examples of tipo (some of them immediately preceded and/or followed by 'o sea') in COLAba (not discussed by Huseby), which seem to indicate that the reformulating function of tipo is not limited to the present data.

Interestingly, in this study the speakers often code-switched to English when reformulating (see excerpts 9 and 10). The various motivations behind code-switching have been studied extensively. In this case, the use of codeswitching appears to be linked to the specific context, that is, to interactions between native and non-native speakers. By discussing the functions of tipo in interactions between native speakers of Argentine Spanish and American undergraduates on a semester abroad, this paper indirectly contributes to the literature on second/foreign language (L2) learning abroad. Current findings suggest that study abroad students can arguably become more proficient users of informal registers (e.g., Dewaele \& Regan, 2001; Kinginger and Farrell, 2004). 
It has been argued that an increased access to interactions with L1 speakers outside of the classroom has the potential of leading to increased exposure and, therefore, to increased use of vernacular language by L2 learners (e.g., Mougeon, Nadasdi and Rehner, 2010). However, few studies have examined the nature of the vernacular vocabulary that study abroad students are exposed to in these types of interactions. A close examination of the language functions of a youth vernacular pragmatic marker such as tipo becomes essential given that study abroad students' expert-like use of pragmatic markers can be taken as an "accurate indicator of the extent to which a speaker is integrated into the local speech community" (Sankoff, Thibault, Nagy and Blondeau, 1997: 193 as cited in Grieve, 2010). As marker of in-group membership, tipo is a language resource that L2 study abroad participants could draw on while in the host community in order to build stronger ties with age-peer local speakers. This would potentially lead to a more thorough social integration in the host culture(s), and ultimately more successful study abroad experiences.

Overall, the results of this study lay the foundation for future pragmatic and sociolinguistic explorations of the uses of tipo in Argentine Spanish vernacular, some of which are identified in the next section.

\section{Future directions}


Although the functions described here were observed in the speech of different speakers in the sample, it is noteworthy that there were marked differences in the proportional preference for tipo between different speakers. For example, Vanesa used it twenty times times as a pragmatic marker, whereas Victoria only used it three times to introduce a hyponym. These differences could be attributed to several factors, including individual preference and differences in participants' sociocultural backgrounds. In fact, this study shows a tendency toward Argentine participants of higher socioeconomic status (Alejandro, Jazmín, Romina, and Vanesa) using tipo more frequently than the rest of the participants. Prior research on the uses of like points to the predominance of its use by middle class (Tannen, 1986; Blyth, Recktenwald and Wang, 1990) or higher social class (Andersen, 1997) speakers. This issue certainly calls for further research, given that other participants of lower socioeconomic status used tipo for some of the same discourse functions, although much less frequently.

The language functions of tipo might also vary according to sociocultural background. For example, only two women of higher socioeconomic background used tipo to introduce reported speech. During a language awareness task (see Fernández, 2013), Jazmín and Vanesa both explained that tipo approximately corresponds to the American English pragmatic marker like. These participants also had rather higher proficiency in English, which could have had an influence 
in their use of tipo. The sample reported here does not serve well as a basis for drawing broad conclusions of this nature, but this is a necessary and fecund line of future sociolinguistic research.

In terms of other promising future research in this area, it is also important to take into account the gender of the speakers. While Huseby's (2010) limited results for tipo seem to point to female preference in the use of tipo, taken as a whole, prior research has produced contradictory results in regard to the relationship between the use of pragmatic markers such as like and gender (Romaine and Lange, 1991; Hasund, 2002; Ferrara and Bell, 1995; DaileyO'Cain, 2000; Blyth et al., 1990). In this study, although tipo was used with pragmatic marking functions by the male Argentine participants, comparisons of its use between Argentine men and women will help to better understand whether it is used as a linguistic enactment of gender.

From these results it appears that tipo shares some pragmatic functions with the English pragmatic marker like (Andersen, 2001). For example, like also has an approximating discourse function as in sort of, around (Underhill, 1988), or approximately (Meehan, 1991), as well as an exemplification function (Andersen, 2001). Tipo also shares with like its quotative function, which has recently received considerable attention in the applied linguistic literature (Barbieri, 2009; Müller, 2005). Traugott (1997) questions the possibility of making 
"cross-language generalizations (...) about the development of discourse particles in terms of both their likely semantic sources and their semanticpragmatic paths (p. 4). Fleischman and Yaguello (2004) call for more crosslanguage pragmatics studies "given the high probability that certain pragmatic functions are if not universal then at least widely attested across languages ( $p$. 143). There is indeed a need for more diachronic and synchronic contrasting studies in this area, which are rather scant potentially due to the lack of spoken corpora and databases of the type discussed here (Jørgensen and Stenström, 2009).

Another future direction is to investigate pragmatic markers that share similarities with tipo. As an example, the Spanish pragmatic marker como 'like' (Kern, 2014; Mihatsch, 2009) appears to share some of the pragmatic functions identified for tipo in the present study, and to be used by young adolescents of (Peninsular and Chilean) Spanish (Jørgensen and Stenström, 2009; Jørgensen, 2011). Como has also been shown to have undergone a process of grammaticalization (Kern, 2014, Mihatsch, 2009) and has been found to have acquired several pragmatic marking functions. For example, it is used with focusing and quotative functions, as a filler, and for exemplification, reformulation, hedging, intensification and codeswitching (Kern, 2014; SánchezMuñoz, 2007; Said-Mohand, 2008; Jørgensen, 2011). As shown in the different 
excerpts, the participants in this study also made extensive use of como as a pragmatic marker. As an illustration, in excerpt 13, Jazmín uses (es) como (que) (together with no sé 'I don't know') with an approximating or hedging function (Vigara Tauste, 1996; Mihatsch, 2009). Examining pragmatic markers with shared similarities may shed more light on participants' expressive preferences vis-a-vis their pragmatic functions.

Finally, in terms of the effects of the medium of communication on the use of the focal pragmatic marker, it is plausible that the lack of immediacy inherent in technology-mediated conversation afforded the participants more chances to exercise their own censoring attitudes toward youth-speak in general (Fernández, 2013), and tipo in particular. This certainly appeared true in relation to features associated with a filler function (such as tipo), which a number of the participants considered necessary to avoid. This avoidance might be fueled by the fact that young speakers' perceived corruption of language in IM and pervasive use of 'empty' pragmatic markers such as tipo "both have been widely identified in the popular imagination with threats" to standard language (Jones and Schieffelin, 2009: 108). The media quite often present both of them in "a negative light" (Jones and Schieffelin, 2009: 108). Huseby (2010) reports on several newspaper articles decrying the loss of the language's (i.e., Argentine Spanish) richness at the hands of thoughtless teenagers, who use words they do 
not know the meanings of (Rey, 2004). Tipo (que), in particular, is singled out as among the bad lexical habits of young speakers adults try to correct (Reina, 2006). This is evidence of the "rising public discourse about the communicative ineptitude of young people" (Thurlow, 2006: 671). In truth, "the patterns of language use (...) documented in IM do not support the view that users are 'simplifying' language to make communication easier or more efficient;" they are actually more concerned with expressivity and infusing IM with "speech-like qualities" (Jones and Schieffelin, 2009: 109). Future research in this area should acknowledge existing layman attitudes toward colloquial lexical features in vernacular usage but fully recognize and build upon their importance for peer group membership and meaning-making in youth speak (face-to-face and online) communities. 


\section{REFERENCES}

Aijmer, 2007

Karin Aijmer

The meaning and functions of the Swedish discourse marker alltså - evidence from translation corpora

Catalan J. Linguist., 6 (2007), pp. 31-59

Andersen, 1997

Gisle Andersen

They like wanna see like how we talk and all that. The use of like as a discourse marker in London teenage speech

M. Ljung (Ed.), Corpus-Based Studies in English, Rodopi, Amsterdam (1997), pp. 37-48

Andersen, 2001

Gisle Andersen

Pragmatic Markers and Sociolinguistic Variation: A Relevance-Theoretic Approach to the Language of Adolescents

John Benjamins, Philadelphia (2001)

Anthony, 2014

Laurence Anthony

AntConc (Version 3.4.3) [Computer Software]

Waseda University, Tokyo, Japan (2014)

Available from http://www.laurenceanthony.net/

Fernández, 2013

Julieta Fernández

Social Networks and Youngspeak in Study Abroad

(Unpublished doctoral dissertation)

The Pennsylvania State University, University Park, Pennsylvania (2013)

Fernández, 2015

Julieta Fernández

General extender use in spoken Peninsular Spanish: metapragmatic awareness and pedagogical implications

J. Span. Lang. Teach., 1 (2015), pp. 1-17

Barbieri, 2009

Federica Barbieri

Quotative be like in American English: ephemeral or here to stay?

Engl. World-Wide, 30 (2009), pp. 68-90

Bauhr, 1994

Gerhard Bauhr

Funciones discursivas de Bueno en español moderno

Lingüíst. Esp. Actual (LEA), 16 (1) (1994), pp. 79-124

Bellés-Fortuño and Fortanet- Gómez, 2009

Begoña Bellés-Fortuño, Inmaculada Fortanet-Gómez

Pragmatic markers in academic discourse: the cases of well and the Spanish counterparts bien and bueno

R. Gómez Morón, M. Padilla Cruz, L. Fernández Amaya, M. Hernández López, O. De la (Eds.), Pragmatics Applied to Language Teaching and Learning, Cambridge Scholars Publishing, Newcastle, UK (2009),

pp. 280-304

Blyth et al., 1990

Carl Blyth Jr., Sigrid Recktenwald, Jenny Wang

I'm like, "say what?!": A new quotative in American oral narrative

Am. Speech, 65 (1990), pp. 215-227

Brinton, 1996

Laurel J. Brinton

Pragmatic Markers in English: Grammaticalization and Discourse Functions 
Mouton de Gruyter, Berlin (1996)

Cenoz, 1998

Jasone Cenoz

Pauses and communication strategies in second language speech. ERIC Document ED 426630

Educational Resources Information Center, Rockville, MD (1998)

Cheng and Warren, 2003

Winnie Cheng, Martin Warren

Indirectness, inexplicitness and vagueness made clearer

Pragmatics, 13 (2003), pp. 381-400

Conde, 2004

Oscar Conde

Diccionario Etimológico del Lunfardo

Taurus, Buenos Aires (2004)

Dailey-O'Cain, 2000

Jennifer Dailey-O'Cain

The sociolinguistic distribution of and attitudes toward focuser like and quotative like

J. Sociolinguist., 4 (2000), pp. 60-80

Dewaele and Regan, 2001

Jean-Marc Dewaele, Vera Regan

The use of colloquial words in advanced French interlanguage

S.H. Foster-Cohen, Anna Nizegorodcew (Eds.), EUROSLA Yearbook 1, John

Benjamins, Amsterdam (2001), pp. 51-68

Escobar and Potowski, 2015

Ana Maria Escobar, Kim Potowski

El Español en los Estados Unidos

Cambridge University Press, Cambridge (2015)

Espíndola, 2002

Athos Espíndola

Diccionario del Lunfardo

Planeta, Buenos Aires (2002)

Ferrara and Bell, 1995

Kathleen Ferrara, Barbara Bell

Sociolinguistic variation and discourse function of constructed dialogue introducers: the case of be+like

Am. Speech, 70 (1995), pp. 265-290

Fleischman and Yaguello, 2004

Suzanne Fleischman, Marina Yaguello

Discourse markers across languages. Evidence from English and French

C.L. Moder, A. Martinovic-Zic (Eds.), Discourse Across Languages and Cultures, John

Benjamins, Philadelphia (2004), pp. 129-147

Foolen, 2012

Ad. Foolen

Pragmatic markers in a sociopragmatic perspective

G. Andersen, K. Aijmer (Eds.), Pragmatics of Society, De Gruyter Mouton, Berlin/Boston(2012), pp. 217-242

Fox Tree, 2010

Jean E. Fox Tree

Discourse markers across speakers and settings

Lang. Linguist. Compass, 4 (5) (2010), pp. 269-281

Fuentes Rodríguez, 1993

Catalina Fuentes Rodríguez

Comportamiento discursivo de bueno, bien, pues bien

Estud. Lingüíst. Univ. Alicante, 9 (1993), pp. 205-221

García Vizcaíno and Martínez-Cabeza, 2005

María José García Vizcaíno, Miguel Martínez-Cabeza 
The pragmatics of well and bueno in English and Spanish Intercult. Pragmat., 2 (1) (2005), pp. 69-92

Grieve, 2010

Averil Grieve

Adolescent identity and pragmatic marker acquisition in a study abroad context

(Unpublished doctoral dissertation)

The University of Melbourne, Melbourne, Australia (2010)

Hasund, 2002

Ingrid Kristine Hasund

Congratulation, like! - Gratulerer, liksom! Pragmatic particles in English and Norwegian

L.E. Breivik, A. Hasselgren (Eds.), From the COLT's Mouth ... and Others. Language Corpora Studies in Honour of Anna-Brita Stenström, Rodopi, Amsterdam (2002), pp. 125-139

Huseby, 2010

Stine Huseby

Las funciones de tipo como marcador del discurso en el lenguaje juvenil de Buenos Aires: Un estudio descriptivo

(MA Thesis)

University of Bergen (2010)

Jones and Schieffelin, 2009

Graham M. Jones, Bambi B. Schieffelin

Enquoting voices, accomplishing talk: uses of be + like in instant messaging

Lang. Commun., 29 (2009), pp. 77-113

ArticlePDF (265KB)

Jørgensen, 2007

Annette Myre Jørgensen

Un corpus oral de lenguaje adolescente

Discurso Oral., 1 (2007), pp. 225-234

Jørgensen, 2009

Annette Myre Jørgensen

En plan used as a hedge in Spanish teenage language

A.-B. Stenström, A.M. Jørgensen (Eds.), Youngspeak in a Multilingual Perspecive, John

Benjamis, Amsterdam (2009), pp. 95-115

Jørgensen, 2011

Annette Myre Jørgensen

Funciones del marcador pragmático como en el lenguaje juvenil español y chileno

M.E. Placencia, C.G. Fernández (Eds.), Pragmática y Comunicación Intercultural en el Mundo

Hispanohablante, Rodopi, London (2011), pp. 207-230

Jørgensen and Martínez Lopez, 2007

Annette Myre Jørgensen, Juan A. Martínez Lopez

Los marcadores del discurso del lenguaje juvenil de Madrid

Rev. Virtual Estud. Ling. - ReVEL, 9 (2007), pp. 1-17

Jørgensen and Stenström, 2009

Annette Myre Jørgensen, Anna-Brita Stenström

Dos marcadores pragmáticos contrastados en el lenguaje juvenil: El Inglés like y el Español como

Esp. Actual, 92 (2009), pp. 103-122

Kern, 2014

Joseph Kern

Como in commute: the travels of a discourse marker across languages

Stud. Hisp. Lusoph. Linguist., 7 (2) (2014), pp. 275-297

Kinginger and Blattner, 2008

Celeste Kinginger, Géraldine Blattner

Histories of engagement and sociolinguistic awareness in study abroad: colloquial French 
L. Ortega, H. Byrnes (Eds.), The Longitudinal Study of Advanced L2 Capacities, Lawrence Erlbaum, New Jersey (2008), pp. 223-246

Kinginger and Farrell, 2004

Celeste Kinginger, Kathleen Farrell

Assessing development of meta-pragmatic awareness in study abroad

Front.: Interdiscip. J. Study Abroad, 10 (2004), pp. 19-42

Kornfeld, 2013

Laura Malena Kornfeld

Atenuadores en la lengua coloquial Argentina

Lingüística, 29 (2) (2013), pp. 17-49

Martínez García, 1990

Hortensia Martínez García

Del pues 'temporal' al 'causal' y 'continuativo'

Actas del Congreso de la Sociedad Española de Lingüística, XX Aniversario, Gredos, Madrid(1990),

pp. 599-610

Meehan, 1991

Teresa Meehan

It's like, "what's happening in the evolution of like?": a theory of grammaticalization

Kansas Work. Pap. Linguist., 16 (1991), pp. 37-51

Mihatsch, 2007

Wiltrud Mihatsch

The construction of vagueness: 'sort of' expressions in Romance languages

G. Radden, K.-M. Köpcke, T. Berg, P. Siemund (Eds.), Aspects of Meaning Construction, John

Benjamis, Amsterdam (2007), pp. 225-246

Mihatsch, 2009

Wiltrud Mihatsch

The grammaticalization of approximators

C. Rossari, C. Ricci, A. Spiridon (Eds.), Grammaticalization and Pragmatics. Facts, Approaches, Theoretical Issues, Emerald, United Kingdom (2009)

Mihatsch, 2010

Wiltrud Mihatsch

The diachrony of rounders and adaptors: approximation and unidirectional change

G. Kaltenböck, W. Mihatsch, S. Schneide (Eds.), New Approaches to Hedging, Emerald, United

Kingdom (2010), pp. 93-122

Mihatsch, 2016

Wiltrud Mihatsch

Type-noun binomials in four Romance languages

Lang. Sci., 53 (2016), pp. 136-159

ArticlePDF (441KB)

Mougeon et al., 2010

Raymond Mougeon, Terry Nadasdi, Katherine Rehner

The Sociolinguistic Competence of Immersions

Multilingual Matters, Bristol (2010)

Müller, 2005

Simone Müller

Discourse Markers in Native and Non-Native English Discourse

John Benjamins, Philadelphia (2005)

Paribakht and Wesche, 1993

T. Sima Paribakht, Bingham Marjorie Wesche

Reading comprehension and second language development in a comprehension-based ESL program TESL Can. J., 11 (1993), pp. 9-29

Pillai, 2006

Stefanie Pillai 
Patterns of repeats in Malaysian English

Multilingua, 25 (2006), pp. 101-113

Porroche Ballesteros, 1996

Margarita Porroche Ballesteros

Las llamadas conjunciones como elementos de conexión en el español conversacional: pues/pero

T. Kotschi, W. Oesterreicher, K. Zimmermann (Eds.), El Español Hablado y la Cultura Oral de España e

Hispanoamérica, Frankfurt am Main, Vervuert (1996), pp. 71-94

$\underline{\text { Reina, } 2006}$

Laura Reina

Cómo entender el lenguaje de los adolescentes

La Nación (April 27, 2006)

Link: http://www.lanacion.com.ar/801003-como-entender-el-lenguaje-de-los-adolescentes

Rey, 2004

Alejandra Rey

Los jóvenes hablan en castellano diferente. Crean palabras o les dan otro significado

La Nación (March 28, 2004)

Link: http://www.lanacion.com.ar/587020-los-jovenes-hablan-en-un-castellano-diferente

Rodríguez, 2002

Félix Rodríguez

El Lenguaje de los Jóvenes

Ariel, S.A., Barcelona (2002)

Romaine and Lange, 1991

Suzanne Romaine, Deborah Lange

The use of like as a marker of reported speech and thought: a case of grammaticalization in progress

Am. Speech, 66 (1991), pp. 227-279

Rymes, 2011

Betsy Rymes

Deference, denial, and beyond: a repertoire approach to mass media and schooling

Rev. Res. Educ., 35 (2011), pp. 208-238

Sánchez-Muñoz, 2007

Ana Sánchez-Muñoz

Style variation in Spanish as a heritage language: a study of discourse markers in academic and nonacademic registers

K. Potowski, R. Cameron (Eds.), Spanish in Contact: Policy, Social and Linguistic Inquiries, John

Benjamins, Amsterdam (2007), pp. 153-171

Said-Mohand, 2008

Aixa Said-Mohand

Aproximación sociolingüística al uso del marcador del discurso como

Rev. Int. Lingüíst. Iberoam., 6 (2) (2008), pp. 71-93

Sankoff et al., 1997

Gillian Sankoff, Pierrette Thibault, Naomi Nagy, Helene Blondeau, Marie-OdileFonollosa, Lucie Gagnon Variation in the use of discourse markers in a language contact situation

Lang. Var. Change, 9 (2) (1997), pp. 191-217

Schmitt, 2010

Norbert Schmitt

Researching Vocabulary. A Vocabulary Research Manual

Palgrave Macmillan, New York (2010)

Schourup, 1985

Lawrence Schourup

Common Discourse Particles in English Conversation

Garland, New York (1985)

Serrano, 1999

Maria Jose Serrano 
Bueno como marcador discursivo de inicio de turno y contraposición: Estudio sociolingüístico Int. J. Sociol. Lang., 140 (1) (1999), pp. 115-134

Stenström, 2006a

Anna-Brita Stenström

The Spanish discourse markers o sea and pues and their English correspondences

K. Aijmer, A.-M. Simon-Vandenbergen (Eds.), Pragmatic Markers in Contrast, Elsevier, Amsterdam (2006), pp. $155-172$

Stenström, 2006b

Anna-Brita Stenström

The Spanish pragmatic marker pues and its English equivalents

A. Renouf, A. Kehoe (Eds.), The Changing Face of Corpus Linguistics, Rodopi, Amsterdam/New York (2006), pp. 263-281

Stenström, 2012

Anna-Brita Stenström

Grammatical Variation in Adolescent Language. The Encyclopedia of Applied Linguistics

Wiley Online Library (2012), 10.1002/9781405198431.wbeal0475

Stenström, 2014

Anna-Brita Stenström

An Introduction to Spoken Interaction

Routledge, New York (2014)

Stenström et al., 2002

Anna-Brita Stenström, Gisle Andersen, Ingrid Kristine Hasund

Trends in Teenage Talk: Corpus Compilation, Analysis and Findings

John Benjamins, Philadelphia (2002)

Tagliamonte, 2016

Sali A. Tagliamonte

Teen Talk: The Language of Adolescents

Cambridge University Press, Cambridge (2016)

Tannen, 1986

Deborah Tannen

Introducing constructed dialogue in Greek and American conversational and literary narrative

F. Coulmas (Ed.), Direct and Indirect Speech, Mouton de Gruyter, Berlin (1986), pp. 311-332

Thurlow, 2006

Crispin Thurlow

From statistical panic to moral panic: the metadiscursive construction and popular exaggeration of new media language in print media

J. Comput. Mediat. Commun., 11 (3) (2006), pp. 667-701

Traugott, 1995

Elizabeth Closs Traugott

The role of the development of discourse markers in a theory of grammaticalization

International Conference on Historical Linguistics XII, Manchester, August 1995 (1995)

(version of 11/97). Available at: http://web.stanford.edu/ traugott/papers/discourse.pdf

Travis, 2005

Catherine E. Travis

Discourse Markers in Colombian Spanish: A Study in Polysemy

Mouton de Gruyter, Berlin/New York (2005)

Underhill, 1988

Robert Underhill

Like is, like, focus

Am. Speech, 63 (1988), pp. 234-246

Vázquez Carranza, 2013

Ariel Vázquez Carranza 
Responding and clarifying. An analysis of pues as a sequential marker in Mexican Spanish talk-ininteractions

Span. Context, 10 (2) (2013), pp. 284-309

Vigara Tauste, 1996

Ana María Vigara Tauste

Español coloquial: Expresión del sentido por aproximación

T. Kotschi, W. Oesterreicher, K. Zimmermann (Eds.), El Español Hablado y la Cultura Oral en España e

Hispanoamérica, Biblioteca Ibero-Americana, Madrid (1996)

Zimmermann, 1996

Klaus Zimmermann

Lenguaje juvenil, comunicación entre jóvenes y oralidad

T. Kotschi, W. Oesterreicher, K. Zimmermann (Eds.), El Español Hablado y la Cultura Oral en España e Hispanoamérica, Biblioteca Ibero-Americana, Madrid (1996)

\section{NOTES}

1 This appears to be the only existing corpus of Argentine teenage Spanish language. It comprises colloquial interactions among teenagers from Buenos Aires (all L1 speakers). Access to COLAba can be requested at http://www.colam.org/om_prosj-espannol.html.

2 Although not all the meanings (certainly not the most recent ones) of tipo have made their way into traditional dictionaries (e.g., the Diccionario de la lengua española from La Real Academia Española), several are included in recent dictionaries of Argentine colloquial vocabulary and lunfardo (e.g., Conde, 2004; Espíndola, 2002).

\section{ACKNOWLEDGEMENTS}

I wish to thank the editor-in-chief, Dr. Neal Norrick, as well as the two anonymous reviewers for their attention to detail and valuable feedback on an earlier version of this manuscript. I would also like to thank the participants, without whose help this paper would not have been possible. All remaining errors are my own responsibility. 